\title{
Penentuan Pemanfaatan Aset Tanah Pemerintah Daerah dengan Sistem Informasi Geografis dan Metode Analitycal Hierarchy Process : Studi Kasus Pemprov Bali
}

\author{
Yudhamanik Kusuma $^{1}$, Linawati $^{2}$, Made Sudarma ${ }^{3}$
}

\begin{abstract}
Land's asset is very important for the community. A good management of asset will be able to add our resources both money and immovable assets. As well as for the asset of Bali Provincial Government. Its own asset that spread throughout Bali will need a proper handling which is supported with Geographic Information System (GIS) and Analytical Hierarchy Process (AHP) system as well, and finally will provide the benefit for the community. Land's asset which used as test data and numbered P.16 is located in Blahbatuh village, Gianyar Regency and other one which has number HP. 129 is located in Renon, Denpasar. Through AHP method, for the P.16 obtained the highest weight on the rice field sector with $25,26 \%$ of weight. Meanwhile for HP.129 got a highest weight in public facility, with $57,04 \%$ of weight. That number of weight is accordance with recent land asset's utilization.
\end{abstract}

Intisari-Aset tanah bagi pemerintah sangatlah penting. Aset tanah yang dikelola dengan baik memberikan nilai tambah kekayaan pada pemerintah. Sama halnya dengan aset tanah Pemprov Bali. Aset tanah yang tersebar di seluruh Bali akan memerlukan penanganan yang dibantu dengan aplikasi Sistem Informasi Geografis (SIG) dan metode Analitycal Hierarchy Process (AHP). SIG mempermudah pengguna, dalam hal ini Biro Aset, dalam menentukan dan pengalamatan lokasi aset tanah. Sedangkan AHP adalah salah satu metode multi-criteria decision making (MCDM) yang digunakan untuk menyelesaikan permasalahan dalam hal pengambilan keputusan. Data uji adalah nomor hak P.16 yang terletak di Desa Blahbatuh, Kabupaten Gianyar, didapatkan angka bobot tertinggi pada tanaman padi dengan nilai bobot $25,26 \%$, dan nomor hak HP.129 di Renon, Denpasar, dengan nilai bobot tertinggi pada fasilitas umum (fasum), dengan nilai bobot sebesar 57,04\%. Nilai bobot yang dihasilkan tersebut sesuai dengan pemanfaatan pada aset tanah tersebut saat ini.

Kata Kunci-Aset Tanah, Pemprov Bali, Sistem Informasi Geografis (SIG), Analitycal Hierarchy Process (AHP)

\footnotetext{
${ }^{1}$ Mahasiswa, Jurusan Teknik Elektro dan Komputer Fakultas Teknik Universitas Udayana, Jln. Jayagiri XIX no.23, Denpasar, 80234, (Hp:08123890600; email: yudhamanik@gmail.com)

${ }^{2,3}$ Dosen, Jurusan Teknik Elektro dan Komputer Fakultas Teknik Universitas Udayana, Jln. Kampus Bukit Jimbaran 80361 INDONESIA. (telp: 0361-703315; fax: 0361-4321; e-mail: linawati@unud..ac.id,sudarma@ee.unud.ac.id)
}

I. PENDAHULUAN

Kekayaan suatu daerah dari aset tanah memiliki nilai yang strategis jika dimanfaatkat dengan baik dan sesuai dengan keadaan. Dalam hal ini aset tanah akan memberikan tambahan bagi pendapatan keuangan daerah sehingga pembangunan yang direncanakan dapat dilaksanakan. Pemprov Bali yang memiliki aset tanah tersebar di setiap kabupaten di Bali diperlukan suatu keputusan tepat dalam hal menentukan pemanfaatan aset tanah. Biro Aset Pemprov Bali yang merupakan perangkat daerah yang bertugas mengelola aset pemerintah[1] mempunyai visi yakni "Terwujudnya pengelolaan barang daerah yang efektif, efisien, ekonomis, transparan dan akuntabel dalam rangka mewujudkan Bali Mandara"[2].

Kemudian untuk dapat melakukan hal tersebut di atas, dalam penelitian ini diterapkan pemakaian aplikasi Sistem Informasi Geografis (SIG)[3][8] yang dipadukan dengan metode Analitycal Hierarchy Process (AHP)[4] sehingga menghasilkan informasi bagi pengambil keputusan untuk menentukan pemanfaatan dari aset tanah. SIG membantu dalam menentukan dan pengalamatan lokasi aset tanah. Dan pemeringkatan pemanfaatan aset tanah menggunakan metode AHP. Peneliti melakukan studi kasus pada aset tanah Pemprov Bali.

Penelitian ini dilakukan di aset tanah Pemprov Bali yang berlokasi di Desa Blahbatuh, Kecamatan Blahbatuh, Kabupaten Gianyar dengan nomor hak P.16[5] dan aset tanah nomor hak HP.129[5] yang berlokasi di Banjar/Dusun Mandala Sari, Desa Dangin Puri Kelod, Kecamatan Denpasar Timur, Kota Denpasar.

\section{METODELOGI}

Penelitian terhadap pemanfaatan aset ini adalah menerapkan SIG dan AHP untuk mendapatkan nilai pemeringkatan terhadap alternatif pemanfaatan aset tanah.

A. Rancangan Alur Penelitian

1. Memilih Data Citra

Data citra yang dipilih adalah berkas data citra yang memiliki ektensi ecw atau shp[6][7]. Data citra ini akan diolah pada aplikasi ArcGIS. Data citra yang dipilih adalah citra Kecamatan Blahbatuh dan citra Kecamatan Denpasar Timur. Pemilihan pengolahan data citra bisa dipilih secara bebas.

2. Digitasi Data Citra[8]

Koordinat aset tanah yang sudah ditemukan pada data citra, kemudian digambarkan batas-batas garis bidang asetnya.

3. Export Data Atribut

Setelah bidang aset tergambar, dilanjutkan dengan membuat tabel atribut. Data atribut adalah database dari bidang aset tanah yang berisikan informasi mengenai keberadaan keadaan di bagian utara, timur, selatan dan 
barat dari lokasi aset. Data ini merupakan data inputan bagi metode AHP

4. Import Data Atribut[9][10]

Import data atribut lokasi aset hasil digitasi ke metode AHP untuk dilakukan pembobotan.

5. Proses Menghitung Nilai Bobot AHP

6. Pengujian Sistem

Pengujian sistem merupakan tahap akhir dari sistem. Pengujian bertujuan untuk mengetahui kebenaran proses kerja sistem dan pilihan yang dihasilkan dari pembobotan merupakan hasil yang tepat.

\section{B. Proses Kerja Digitasi}

Proses digitasi dijelaskan sebagai berikut :

1. Data Citra

Gambar citra yang akan diolah dibuka pada aplikasi ArcGIS.

2. Menginput koordinat

Koordinat XY terdapat pada dokumen identitas aset tanah.

3. Menggaris bidang aset tanah

Untuk menggaris bidang aset tanah pada aplikasi ArcGIS dengan terlebih dahulu membuat berkas baru yang berformat shapefile. Kemudian dilakukan proses editing. Proses editing bertujuan untuk menggambarkan bidang aset tanah.

4. Membuat data atribut

Data ini berisikan data keadaan di bagian utara, timur, selatan dan barat dari aset tanah. Data ini menjadi data inputan pada proses pembobotan di metode AHP.

\section{Menghitung Nilai Bobot AHP}

Proses pada AHP terlihat seperti Gambar 1 berikut ini.

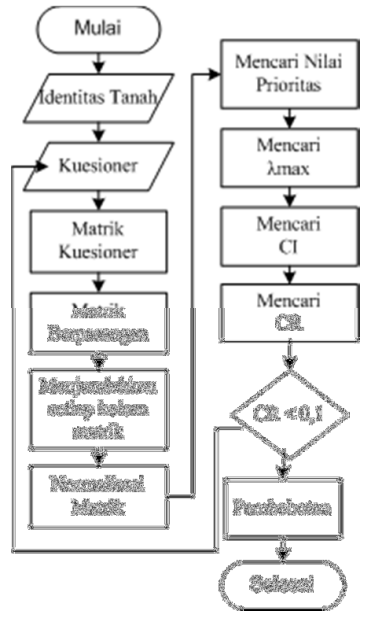

Gambar 1: Diagram Alir Perhitungan AHP

Penjelasan Gambar 1 adalah sebagai berikut.

1. Identitas tanah adalah data mengenai keadaan fisik dan aksesibilitas tanah

2. Kuesioner adalah deretan angka yang menyatakan perbandingan antara item-item pada kriteria maupun item-item pada alternatif.

Yudhamanik Kusuma : Penentuan Pemanfaatan Aset Tanah...
3. Matrik kuesioner adalah tabel yang menyususun angkaangka perbandingan yang dipilih.

4. Matrik berpasangan adalah aksioma resiprokal AHP

5. Menjumlahkan setiap kolom matrik untuk mendapatkan jumlah total angka setiap kolom.

6. Normalisasi matrik adalah membagi setiap angka di setiap kolom dengan jumlah kolomnya. Nilai normalisasi setiap kolom bernilai satu.

7. Nilai Prioritas adalah jumlah total baris dibagi dengan banyaknya kriteria atau alternatif.

8. Menghitung $\lambda$ mak

9. Menghitung CI

10. Menghitung $\mathrm{CR}$, jika nilai $\mathrm{CR}>0,1$, maka matrik berpasangan konsisten dan dapat dilakukan pembobotan.

\section{HASIL DAN PEMBAHASAN}

Hasil digitasi aset tanah P.16 dan HP.129 seperti nampak pada Gambar 2 dan Gambar 3 berikut ini.

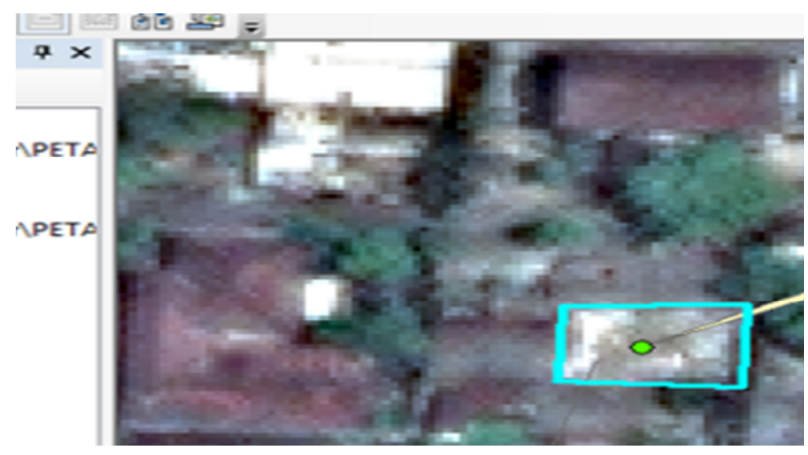

Gambar 2: Digitasi P.16

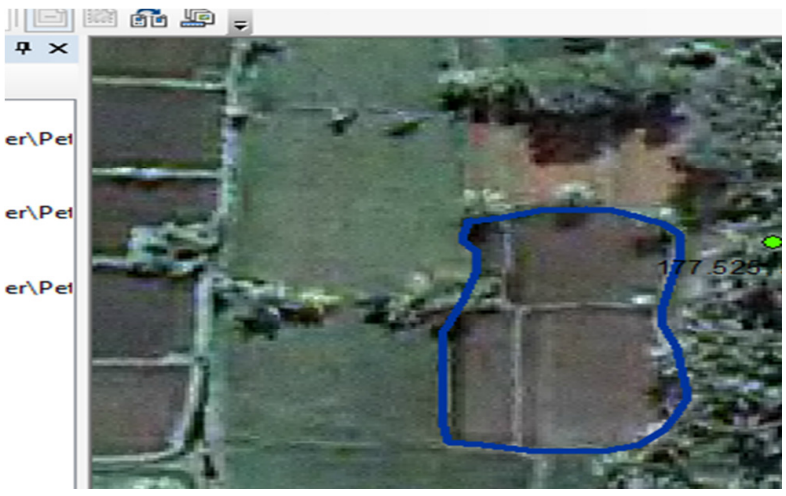

Gambar 3. Digitasi HP.129

Hasil digitasi aset tanah P.16 dan HP.129 pada gambar 2 dan gambar 3 ditandai dengan garis berwarna untuk memperjelas bentuknya yang menggambar bidang tanah. Bentuk bidang aset tanah yang digambarkan sesuai dengan data dari Badan Pertanahan Nasional yang ada di Kabupaten Gianyar dan Kota Denpasar. 
Atribut untuk aset P.16 dan aset HP.129 seperti tampak pada Gambar 4 dan Gambar 5. Data atribut aset tanah ini diinput pada aplikasi SIG untuk nantinya di import ke metode AHP.

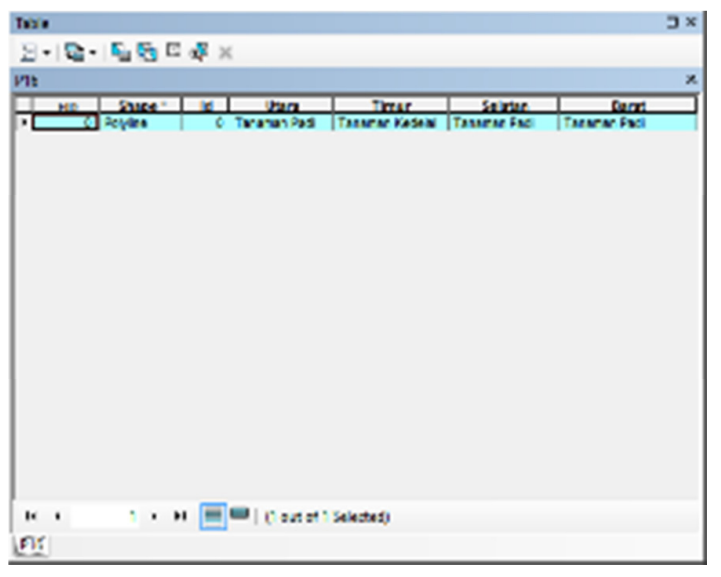

Gambar 4: Atribut P.16

Lokasi aset tanah P.16 dibagian utara adalah tanaman padi, di bagian timurnya terdapat tanaman kedelai, di bagian selatan ditatamin tanaman padi dan pada bagian sebelah barat terdapat tanaman padi. Dengan demikian alternatif untuk aset P.16 berturut-turut adalah tanaman padi, tanaman kedelai, tanaman padi, tanaman padi.

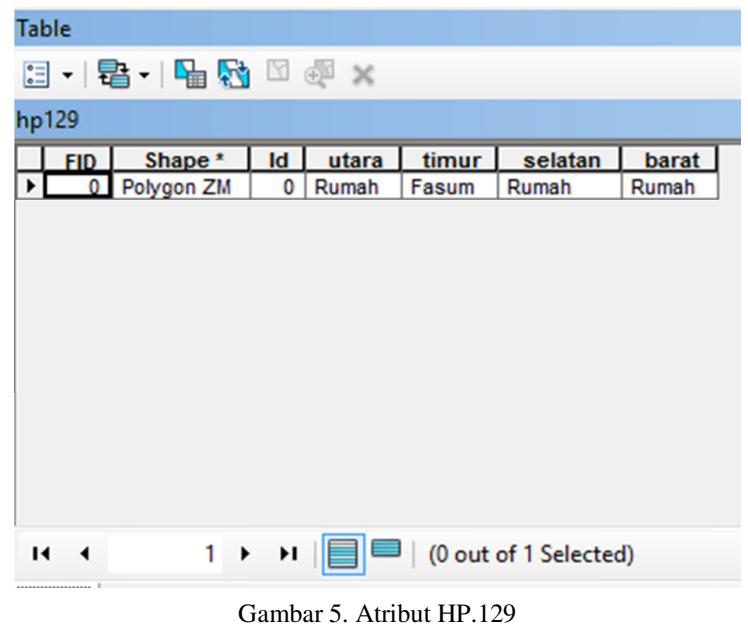

Terhadap aset tanah HP.129 didapatkan data bahwa kondisi saat ini di bagian utaranya adalah rumah, di bagian timurnya adalah fasum, bagian barat terdapat rumah dan pada bagian selatan terdapat rumah. Dari keberadaan posisi aset tanah maka di dapatkan alternatif untuk aset HP. 129 adalah terdiri dari rumah, fasum, rumah dan rumah. Proses pembobotan untuk aset tanah P.16 diawali dengan terlebih dahulu menyusun angka matrik kriteria yang telah dipilih sebelumnya ke dalam tabel matrik seperti terlihat pada Tabel 1 berikut.

Setelah dilakukan proses perhitungan bahwa angka matrik bersifat konsisten, terbukti dengan nilai $\mathrm{CR}$ matrik kriteria adalah 0,07 lebih kecil dari 0,1, sehingga dapat dilanjutkan untuk mencari nilai CR pada masing-masing kriteria yang mempengaruhi alternatif.
TABEL 1

TABEL MATRIK KRITERIA UNTUK P.16

\begin{tabular}{|c|c|c|c|c|c|c|c|}
\hline Kriteria & $\begin{array}{l}\text { Kualitas } \\
\text {-alu } \\
\text {-intas } \\
\text { Sekitar }\end{array}$ & $\begin{array}{l}\text { Bentuk } \\
\text { Medan }\end{array}$ & $\begin{array}{l}\text { Ketingg } \\
\text { an }\end{array}$ & $\begin{array}{l}\text { Kemirin } \\
\text { gan } \\
\text { Tanah }\end{array}$ & $\begin{array}{l}\text { Kedala } \\
\text { man } \\
\text { Efektif } \\
\text { Tanah }\end{array}$ & Tekstu & $\begin{array}{l}\text { Jenis } \\
\text { Tanah }\end{array}$ \\
\hline Kualitas Lingkungan Pemukiman Sekitar & 7 & 7 & 7 & 7 & 7 & 7 & 7 \\
\hline Kualitas Lalu Lintas Sekitar & & 1 & 7 & 7 & 7 & 7 & 7 \\
\hline Bentuk Medan & & & 1 & 1 & 1 & 1 & 1 \\
\hline Ketinggian & & & & 1 & 1 & 1 & 1 \\
\hline Kemiringan Tanah & & & & & 1 & 1 & 1 \\
\hline Kedalaman Efektif Tanah & & & & & & 1 & 1 \\
\hline Tekstur Tanah & & & & & & & 1 \\
\hline Nilai Lamda : 8.69726 & & & & & & & \\
\hline Nilai Cl: & & & & & & & \\
\hline Nilai CR : & & & & & & & \\
\hline
\end{tabular}

TABEL 2

NILAI CR ALTERNATIF ASET TANAH P.16 AKIBAT PENGARUH DARI KUALITAS LINGKUNGAN PEMUKIMAN SEKITAR

\begin{tabular}{|c|c|c|c|}
\hline \multicolumn{2}{|c|}{ Angka Matrik Altemative terhadap } & \multicolumn{2}{|l|}{ Kual } \\
\hline Alternative & \begin{tabular}{|l|} 
Tanaman \\
Kedelai
\end{tabular} & \begin{tabular}{|l|} 
Tanaman \\
Padi
\end{tabular} & \begin{tabular}{|l|} 
Tanaman \\
Padi
\end{tabular} \\
\hline Tanaman Padi & 1 & 1 & 1 \\
\hline Tanaman Kedelai & & 1 & 1 \\
\hline Tanaman Padi & & & $\overline{11}$ \\
\hline Nilai Lamda : 4.0 & & & \\
\hline Nilai $\mathrm{Cl}$ : & & & \\
\hline Nilai CR : & & & \\
\hline
\end{tabular}

Pada tabel 2 dilakukan perhitungan prioritas alternatif akibat pengaruh dari kualitas lingkungan pemukiman sekitar. Hasil yang diperoleh untuk nilai CR adalah sama dengan 0 , matrik bersifat konsisten dan dilanjutkan ke alternatif lainnya.

TABEL 3
NILAI CR ALTERNATIF ASET TANAH P.16 AKIBAT PENGARUH
DARI KUALITAS LALU LINTAS SEKITAR
Angka Matrik Alternative terhadap : Kualitas Lalu Lintas Sekitar
\begin{tabular}{|l|c|c|c|}
\hline Alternative & $\begin{array}{l}\text { Tanaman } \\
\text { Kedelai }\end{array}$ & $\begin{array}{l}\text { Tanaman } \\
\text { Padi }\end{array}$ & $\begin{array}{l}\text { Tanaman } \\
\text { Padi }\end{array}$ \\
\hline Tanaman Padi & 1 & 1 & 1 \\
\hline Tanaman Kedelai & & 1 & 1 \\
\hline Tanaman Padi & & & 1 \\
\hline Nilai Lamda : 4.0 & & & \\
Nilai CI: $\quad 0.0$ & & \\
Nilai CR: $\quad 0.0$ &
\end{tabular}

Tabel 3 terbentuk akibat pengaruh dari kualitas lalu lintas sekitar. Kemudian dilakukan perhitungan. Hasil yang diperoleh untuk nilai $\mathrm{CR}$ adalah sama dengan 0, matrik bersifat konsisten dan dilanjutkan ke alternatif lainnya.

Dari perhitungan matrik yang dipengaruhi oleh bentuk medan seperti pada Tabel 4, dihasilkan nilai CR yang sama dengan 0 , ini berarti angka matrik bersifat konsisten. Untuk itu proses kembali dilanjutkan. Selanjutnya mencari nilai CR akibat pengaruh dari ketinggian, seperti tampak pada Tabel 5 berikut. 
TABEL 4

NILAI CR ALTERNATIF ASET TANAH P.16 AKIBAT PENGARUH DARI BENTUK MEDAN

Angka Matrik Alternative terhadap : Bentuk Medan

\begin{tabular}{|l|c|c|c|}
\hline \multicolumn{1}{|c|}{ Alternative } & $\begin{array}{l}\text { Tanaman } \\
\text { Kedelai }\end{array}$ & $\begin{array}{l}\text { Tanaman } \\
\text { Padi }\end{array}$ & $\begin{array}{l}\text { Tanaman } \\
\text { Padi }\end{array}$ \\
\hline Tanaman Padi & 1 & 1 & 1 \\
\hline Tanaman Kedelai & & 1 & 1 \\
\hline Tanaman Padi & & & 1 \\
\hline
\end{tabular}

Nilai Lamda : 4.0

Nilai $\mathrm{Cl}: \quad 0.0$

Nilai CR : $\quad 0.0$

TABEL 5

NILAI CR ALTERNATIF ASET TANAH P.16 AKIBAT PENGARUH DARI KETINGGIAN

Angka Matrik Alternative terhadap : Ketinggian

\begin{tabular}{|l|c|c|c|}
\hline \multicolumn{1}{|c|}{ Alternative } & $\begin{array}{l}\text { Tanaman } \\
\text { Kedelai }\end{array}$ & $\begin{array}{l}\text { Tanaman } \\
\text { Padi }\end{array}$ & $\begin{array}{l}\text { Tanaman } \\
\text { Padi }\end{array}$ \\
\hline Tanaman Padi & 1 & 1 & 1 \\
\hline Tanaman Kedelai & & 1 & 1 \\
\hline Tanaman Padi & & & 1 \\
\hline
\end{tabular}

Nilai Lamda : 4.0

Nilai $\mathrm{Cl}: \quad 0.0$

Nilai CR : $\quad 0.0$

Hasil nilai $\mathrm{CR}$ yang diperoleh adalah 0 , angka matrik konsisten, sehingga proses perhitungan nilai CR kembali dilanjutkan ke alternatif lain.

TABEL 6 NILAI CR ALTERNATIF ASET TANAH P.16 AKIBAT PENGARUH
DARI KEMIRINGAN TANAH

Angka Matrik Alternative terhadap : Kemiringan Tanah

\begin{tabular}{|l|c|c|c|}
\hline \multicolumn{1}{|c|}{ Alternative } & $\begin{array}{l}\text { Tanaman } \\
\text { Kedelai }\end{array}$ & $\begin{array}{l}\text { Tanaman } \\
\text { Padi }\end{array}$ & $\begin{array}{l}\text { Tanaman } \\
\text { Padi }\end{array}$ \\
\hline Tanaman Padi & 1 & 1 & 1 \\
\hline Tanaman Kedelai & & 1 & 1 \\
\hline Tanaman Padi & & & 1 \\
\hline
\end{tabular}

Nilai Lamda : 4.0

Nilai $\mathrm{Cl}: \quad 0.0$

Nilai CR : $\quad 0.0$

Pengaruh kriteria kemiringan tanah yang nampak pada tabel 6 di atas terhadap alternatif menghasilkan nilai CR yang sama dengan nol atau lebih kecil dari angka 0,1 sebagai syarat konsisten. Oleh karena itu proses dilanjutkan untuk mencari nilai CR pada alternatif berikutnya. Berikut pada tabel 7 dibawah ini tersusun tabel matrik alternatif yang dipengaruhi oleh kedalam efektif tanah.

Nilai CR untuk tabel 7 aset tanah akibat pengaruh kedalaman efektif tanah sama dengan 0 , sehingga tabel matrik bersifat konsisten. Dilanjutkan dengan menghitung nilai konsistensi ratio akibat pengaruh dari tekstur tanah. Angka matrik ditunjukkan pada tabel 8 di bawah ini.

Yudhamanik Kusuma : Penentuan Pemanfaatan Aset Tanah...
TABEL7

NILAI CR ALTERNATIF ASET TANAH P.16 AKIBAT PENGARUH DARI KEDALAMAN EFEKTIF TANAH

Angka Matrik Alternative terhadap : Kedalaman Efektif Tanah

\begin{tabular}{|l|c|l|l|}
\hline \multicolumn{1}{|c|}{ Alternative } & $\begin{array}{l}\text { Tanaman } \\
\text { Kedelai }\end{array}$ & $\begin{array}{l}\text { Tanaman } \\
\text { Padi }\end{array}$ & $\begin{array}{l}\text { Tanaman } \\
\text { Padi }\end{array}$ \\
\hline Tanaman Padi & 1 & 1 & 1 \\
\hline Tanaman Kedelai & & 1 & 1 \\
\hline Tanaman Padi & & & 1 \\
\hline
\end{tabular}

Nilai Lamda : 4.0

Nilai $\mathrm{Cl}: \quad 0.0$

Nilai CR : $\quad 0.0$

TABEL 8

NILAI CR ALTERNATIF ASET TANAH P.16 AKIBAT PENGARUH DARI TEKSTUR TANAH

Angka Matrik Alternative terhadap: Tekstur Tanah

\begin{tabular}{l|c|c|c|}
\hline \multicolumn{1}{|c|}{ Alternative } & $\begin{array}{l}\text { Tanaman } \\
\text { Kedelai }\end{array}$ & $\begin{array}{l}\text { Tanaman } \\
\text { Padi }\end{array}$ & $\begin{array}{l}\text { Tanaman } \\
\text { Padi }\end{array}$ \\
\hline Tanaman Padi & 3 & 1 & 1 \\
\hline Tanaman Kedelai & & $1 / 3$ & $1 / 3$ \\
\hline Tanaman Padi & & & 1 \\
\hline Nilai Lamda : 4.0 & & \\
Nilai Cl: $\quad 0.0$ & 0.0
\end{tabular}
Nilai CR: $\quad 0.0$

Hasil perhitungan menghasilkan nilai CR sama dengan 0 . Angka matrik pada tabel 8 sebagai input, bersifat konsisten, dapat dilanjutkan ke aletnatif lain, seperti terlihat pada tabel 9 di bawah ini.

TABEL 9

NILAI CR ALTERNATIF ASET TANAH P.16 AKIBAT PENGARUH DARI JENIS TANAH

Angka Matrik Alternative terhadap : Jenis Tanah

\begin{tabular}{|c|c|c|c|}
\hline Alternative & $\begin{array}{l}\text { Tanaman } \\
\text { Kedelai }\end{array}$ & $\begin{array}{l}\text { Tanaman } \\
\text { Padi }\end{array}$ & $\begin{array}{l}\text { Tanaman } \\
\text { Padi }\end{array}$ \\
\hline Tanaman Padi & 1 & 1 & 1 \\
\hline Tanaman Kedelai & & 1 & 1 \\
\hline Tanaman Padi & & & 1 \\
\hline Nilai Lamda : 4.0 & & & \\
\hline Nilai $\mathrm{Cl}$ : & & & \\
\hline Nilai CR : & & & \\
\hline
\end{tabular}

Dari perhitungan nilai CR akibat pengaruh dari jenis tanah di tabel 9 didapat nilai 0, yang berarti angka matrik bersifat konsisten. Dengan telah dilakukannya perhitungan pada semua tabel matrik alternatif, terakhir dilakukan perhitungan pembobotan.

Pembobotan nilai matrik kriteria dengan matrik alternatif terhadap aset tanah P.16 yang paling besar mendapatkan pilihan terletak pada tanaman padi yakni sebesar 0,25255 atau $25,26 \%$, disusul kemudian oleh tanaman padi 0,25255 atau $25,26 \%$, selanjutnya tanaman padi 0,25255 atau $25,26 \%$ dan 0,24236 atau $24,24 \%$ pada tanaman kedelai. Hasil dari perhitungan pembobotan yang menghasilkan angka tertinggi pada tananan padi memiliki kesamaan dengan keberadaan aset tersebut yang sedang ditanami tanaman padi. Nilai bobot yang 
dihasilkan tersebut sesuai dengan pemanfaatan pada aset tanah tersebut saat ini.

Selanjutnya pembobotan untuk aset tanah nomor HP.129. pada aset tanah HP.129 yang menjadi altenatif berdasarkan kelompok terdiri dari rumah dan fasum. Tabel 10 di bawah ini adalah tabel matrik kriteria aset tanah HP.129.

TABEL 10

TABEL MATRIK KRITERIA UNTUK HP.129

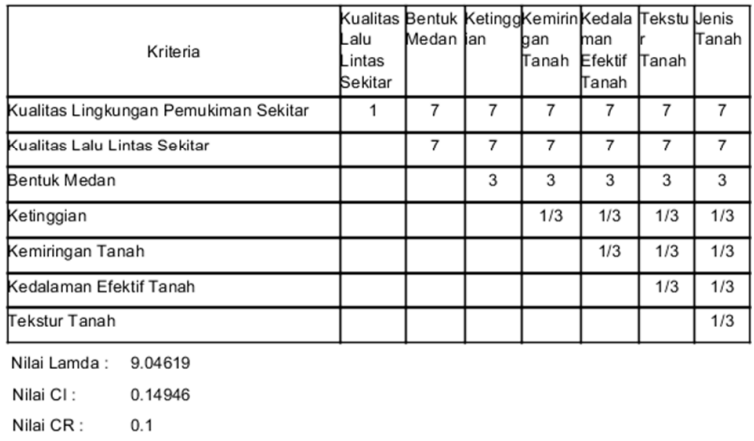

Perhitungan pada tabel matrik di atas untuk mencari nilai CR, mendapatkan angka CR sama dengan 0. Matrik kriteria aset tanah HP.129 bersifat konsisten. Kemudian dilanjutkan untuk mencari nilai kosistensi ratio pada tabel matrik alternatif lainnya.

TABEL 11

NILAI CR MATRIK ALTERNATIF ASET TANAH HP.129 AKIBAT PENGARUH DARI KUALITAS LINGKUNGAN PEMUKIMAN SEKITAR Angka Matrik Alternative terhadap : Kualitas Lingkungan Pemukiman Sekitar

\begin{tabular}{|c|c|c|c|}
\hline Alternative & Fasum & Rumah & Rumah \\
\hline Rumah & $1 / 7$ & 1 & 1 \\
\hline Fasum & & 7 & 7 \\
\hline Rumah & & & 1 \\
\hline Nilai Lamda : & & & \\
\hline Nilai Cl: & & & \\
\hline Nilai $C R$ : & & & \\
\hline
\end{tabular}

TABEL 12

NILAI CR MATRIK ALTERNATIF ASET TANAH HP.129 AKIBAT PENGARUH DARI KUALITAS LALU LINTAS SEKITAR Angka Matrik Alternative terhadap : Kualitas Lalu Lintas Sekitar

\begin{tabular}{|c|c|c|c|}
\hline Alternative & Fasum & Rumah & Rumah \\
\hline Rumah & $1 / 7$ & 1 & 1 \\
\hline Fasum & & 7 & 7 \\
\hline Rumah & & & 1 \\
\hline
\end{tabular}

Nilai Lamda : 4.0

Nilai $\mathrm{Cl}$ : $\quad 0.0$

Nilai CR : $\quad 0.0$

Pengaruh kualitas lingkungan pemukiman sekitar di bentuk matrik seperti tabel 11 . Proses perhitungan nilai CR menghasilkan angka sama 0 yaitu angka tabel matrik konsisten. Demikian juga tabel 12 menunjukkan pengaruh kualitas lalu lintas sekitar terhadap aset tanah HP.129. Hasil nilai CR didapat sama dengan 0 yang bersifat konsisten.
TABEL 13

NILAI CR MATRIK ALTERNATIF ASET TANAH HP.129 AKIBAT PENGARUH DARI BENTUK MEDAN

Angka Matrik Alternative terhadap : Bentuk Medan

\begin{tabular}{l|l|l|l|}
\hline \multicolumn{1}{|c|}{ Alternative } & Fasum & Rumah & Rumah \\
\hline Rumah & $1 / 7$ & 1 & 1 \\
\hline Fasum & & 7 & 7 \\
\hline Rumah & & & 1 \\
Nilai Lamda : 4.0 & & \\
Nilai Cl : $\quad 0.0$ & \\
Nilai CR : 0.0 &
\end{tabular}

Angka matrik pada tabel 13 merupakan angka matrik akibat pengaruh dari bentuk medan. Perhitungan terhadap matrik mendapatkan angka CR sebesar 0. Maka perhitungan dapat dilanjutkan ke matrik berikut karena tabel matrik bersifat konsisten.

TABEL 14

NILAI CR MATRIK ALTERNATIF ASET TANAH HP.129 AKIBAT PENGARUH DARI KETINGGIAN

Angka Matrik Alternative terhadap : Ketinggian

\begin{tabular}{|c|c|c|c|}
\hline Alternative & Fasum & Rumah & Rumah \\
\hline Rumah & 5 & 1 & 1 \\
\hline Fasum & & $1 / 5$ & $1 / 5$ \\
\hline Rumah & & & 1 \\
\hline Nilai Lamda : $\quad 4.0$ & & & \\
\hline Nilai Cl : & & & \\
\hline Nilai CR : & & & \\
\hline
\end{tabular}

Akibat pengaruh dari ketinggian nilai matrik disusun seperti pada tabel 14. Setelah dilakukan perhitungan dari angka yang dipilih mengahasilkan nilai $\mathrm{CR}$ sebesar 0 . Matrik bersifat konsisten.

TABEL 15

NILAI CR MATRIK ALTERNATIF ASET TANAH HP.129 AKIBAT PENGARUH DARI KEMIRINGAN TANAH

Angka Matrik Alternative terhadap : Kemiringan Tanah

\begin{tabular}{|l|l|l|l|}
\hline \multicolumn{1}{|c|}{ Alternative } & Fasum & Rumah & Rumah \\
\hline Rumah & 1 & 1 & 1 \\
\hline Fasum & & 1 & 1 \\
\hline Rumah & & & 1 \\
\hline
\end{tabular}

Nilai Lamda : 4.0

Nilai $\mathrm{Cl}: \quad 0.0$

Nilai CR : $\quad 0.0$

Nilai CR akibat pengaruh kemiringan tanah didapat sebesar 0 pada tabel 15. Matrik bersifat konsisten, dapat dilanjutkan.

Selanjutnya, tabel matrik akibat pengaruh dari kedalaman efektif tanah disusun seperti pada tabel 16. Dari hasil perhitungan untuk mengetahui apakah matrik bersifat konsisten, didapatkan nilai CR sebesar 0 , artinya angka matrik konsisten. 
TABEL 16

NILAI CR MATRIK ALTERNATIF ASET TANAH HP.129 AKIBAT PENGARUH DARI KEDALAMAN EFEKTIF TANAH Angka Matrik Alternative terhadap : Kedalaman Efektif Tanah

\begin{tabular}{|l|l|l|l|}
\hline \multicolumn{1}{|c|}{ Alternative } & Fasum & Rumah & Rumah \\
\hline Rumah & & & \\
\hline Fasum & $1 / 5$ & 1 & 1 \\
\hline Rumah & & 5 & 5 \\
\hline
\end{tabular}

Nilai Lamda : 4.0

Nilai $\mathrm{Cl}: \quad 0.0$

Nilai CR : $\quad 0.0$

Berikut tabel matrik akibat pengaruh dari tekstur tanah. Angka yang dimasukkan seperti ditunjukkan pada tabel 17 .

TABEL 17

NILAI CR MATRIK ALTERNATIF ASET TANAH HP.129 AKIBAT PENGARUH DARI TEKSTUR TANAH

Angka Matrik Alternative terhadap : Tekstur Tanah

\begin{tabular}{|l|c|c|c|}
\hline \multicolumn{1}{|c|}{ Alternative } & Fasum & Rumah & Rumah \\
\hline Rumah & 5 & 1 & 1 \\
\hline Fasum & & $1 / 5$ & $1 / 5$ \\
\hline Rumah & & & 1 \\
\hline
\end{tabular}

Nilai Lamda : 4.0

Nilai $\mathrm{Cl}: \quad 0.0$

Nilai CR : $\quad 0.0$

Perhitung tabel 17 menghasilkan angka CR sama dengan 0. Proes dilanjutkan ke matrik berikutnya karena tabel matrik akibat pengaruh tekstur tanah bersifat konsisten.

TABEL 18

NILAI CR MATRIK ALTERNATIF ASET TANAH HP.129 AKIBAT PENGARUH DARI JENIS TANAH

Angka Matrik Alternative terhadap : Jenis Tanah

\begin{tabular}{|l|c|c|c|}
\hline \multicolumn{1}{|c|}{ Alternative } & Fasum & Rumah & Rumah \\
\hline Rumah & 5 & 1 & 1 \\
\hline Fasum & & $1 / 5$ & $1 / 5$ \\
\hline \hline Rumah & & & 1 \\
\hline
\end{tabular}

Nilai Lamda : 4.0

Nilai $\mathrm{Cl}$ : $\quad 0.0$

Nilai CR : $\quad 0.0$

Proses terakhir pembobotan untuk aset tanah HP.129 adalah mencari nilai CR akibat pengaruh jenis tanah. Tabel matrik disusun seperti tabel 19. Hasil perhitungan nilai CR adalah 0 . Karena semua matrik alternatif konsisten, lanjut dibobotkan.

Dari hasil pembobotan nilai matrik kriteria dengan matrik alternatif angka paling besar terletak pada alternatif fasum yakni sebesar 0,57044 atau $57,04 \%$, disusul kemudian oleh rumah 0,14319 atau $14,32 \%$, selanjutnya rumah 0,14319 atau $14,32 \%$, dan 0,14319 atau $14,32 \%$, pada rumah yang lain. Pilihan tertinggi kepada fasum. Sesuai dengan kondisi saat ini, aset tanah HP.129 masih menjadi rung terbuka yang dipakai Yudhamanik Kusuma : Penentuan Pemanfaatan Aset Tanah... oleh masyarakat untuk melaksanakan kegiatan kemasyarakatan ataupun sebagai tempat bagi anak-anak bermain.

\section{KESIMPULAN}

Berdasarkan penelitian, perancangan sistem, implementasi dan pengujian hasil penelitian yang telah dilakukan terhadap aset tanah yang bertujuan untuk mengetahui pemanfaatannya, maka dapat diambil simpulan sebagai berikut :

1. Menentukan pemanfaatan aset tanah Pemprov Bali dengan mengetahui data keberadaan posisi aset yang kemudian diolah dengan SIG dan metode AHP dapat menghasilkan nilai-nilai alternatif yang dapat menjadi pilihan dalam pemanfaatan aset tanah.

2. Kriteria yang paling mempengaruhi dalam pembobotan terhadap aset tanah P.16 dan HP.129 adalah pada kriteria kualitas lingkungan pemukiman sekitar. Oleh sebab itu, dalam pemanfaatan aset tanah, Pemprov Bali lebih mengutamakan keadaan dan kondisi pemukiman masyarakat sekitar lokasi aset tanah.

3. Hasil perhitungan bobot dengan metode AHP terhadap aset tanah P.16, mendapat nilai tertinggi pada tanaman padi dengan nilai bobot $25,26 \%$ dan nilai terendah pada tanaman kedelai dengan nilai bobot $24,24 \%$. Sehingga pemanfaatan aset tanah P.16 dipilih adalah untuk menanam tanaman padi.

4. Hasil perhitungan bobot metode AHP terhadap aset tanah dengan nomor hak HP.129 nilai tertinggi berada pada alternatif fasum dengan nilai $57,04 \%$ dan terendah pada alternatif rumah dengan nilai $14,32 \%$. Oleh karena itu pemanfaatan aset tanah HP.129 baik dimanfaatkan sebagai fasum.

\section{REFERENSI}

[1] Pemerintah Provinsi Bali, Peraturan Gubernur Bali Nomor 33 Tahun 2008 Tentang Rincian Tugas Pokok Biro Aset Setda Provinsi Bali.

[2] Biro Aset Setda Provinsi Bali, 2013-2018, Dokumen Rencana Strategis.

[3] I Wayan Nuarsa, Tutorial ArcView GIS, Tersedia pada: URL: http://gis.nuarsa.info/

[4] Saaty, T.L., 1980. The Analytic Hierarchy Process: Planning, Priority Setting, Resource Allocation, McGraw-Hill, New York, NY, pp: 437.

[5] Biro Aset Setda Provinsi Bali, 2014, Data Bidang Tanah.

[6] Pemerintah Kabupaten Gianyar, Peraturan Daerah Kabupaten Gianyar Nomor 12 Tahun 2012 Tentang Rencana Tata Ruang Wilayah Kabupaten Gianyar Tahun 2010-2030

[7] Pemerintah Kota Denpasar, Peraturan Daerah Kota Denpasar Nomor 27 Tahun 2011 Tentang Rencana Tata Ruang Wilayah Kota Denpasar Tahun 2011-2031

[8] Anonim, Pengelolaan Data Geospasial, tersedia pada: Url: http://www.cifor.org/publications/pdf_files/Books/SIGeografis/SIGpart-2.pdf

[9] Bunafit Nugroho, 2014, PHP dan MySQL dengan Editor Dreamweaver $M X$. Penerbit Andi

[10] Ivor Horton, 1999, Beginning Java 2, Wrox Press Ltd. 